\title{
Oyster-Predator Dynamics and Climate Change ${ }^{1}$
}

\author{
Gabrielle Love, Shirley Baker, and Edward V. Camp ${ }^{2}$
}

\section{Abstract}

Oysters are one of the most important natural resources found in coastal and estuarine areas of Florida, but some Florida oyster populations appear to be declining.

Environmental factors such as changes in temperature or salinity may affect oysters, and another possible driver of oyster population decline is increased mortality from oyster predators, including marine snails. This article describes how a changing climate may affect oysters directly by changing their environment but also indirectly by affecting their predators.

\section{Introduction}

Eastern oysters (Crassostrea virginica) are commonly found in estuaries and bays in the Gulf of Mexico. They build recognizable reef structures that are well-recognized for providing many services for both the environment and for humans. These services include water nutrient cycling, creation of reef habitats for fish and crustaceans, carbon sequestration, protection of shorelines from erosion and storms by buffering wave energy, increased overall biodiversity, and sustaining commercial and recreational oyster fisheries important for many coastal communities (Grabowski and Peterson 2007; Grabowski et al. 2012). Oyster fisheries have historically provided a reliable source of protein and income for these communities, with Gulf of Mexico oyster landings valued at over $\$ 100$ million USD in 2017 (NOAA 2019). Therefore, the health of oyster populations is incredibly important to ecosystems and for human interests.

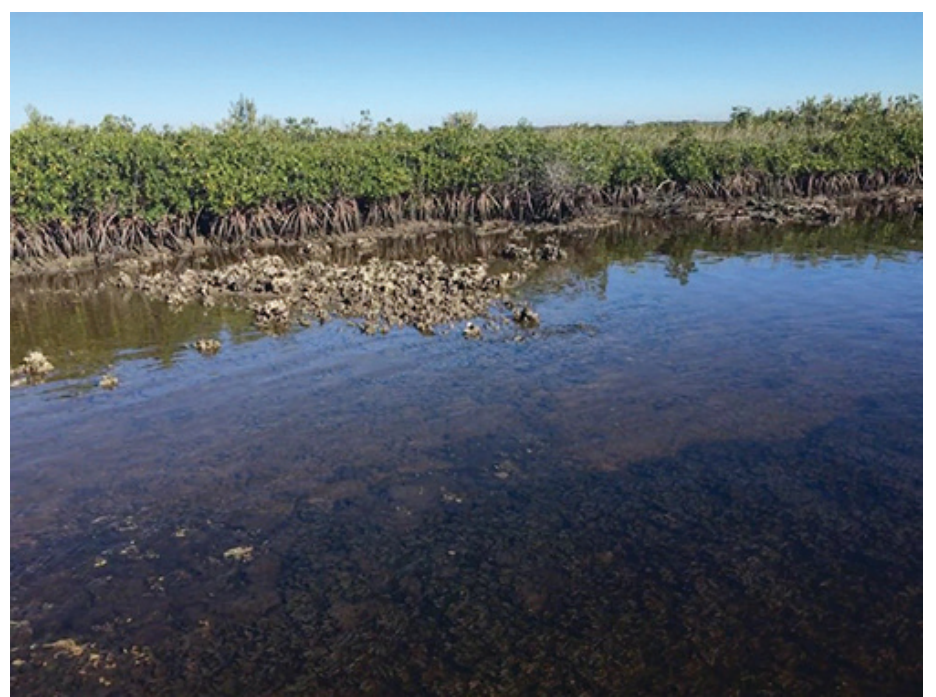

Figure 1. Oysters are a critical part of coastal ecosystems in Florida. Credits: E. V. Camp, UF/IFAS.

Oyster reef health involves many aspects, but one of the most important is oyster natural mortality (i.e., death by environmental, physical, or ecological causes rather than oyster fishing). Natural mortality has been considered one of the major drivers of oyster population declines, including the decline of the Apalachicola Bay oyster fishery (Pine et al. 2015; Kimbro et al. 2017). Oyster natural mortality is complicated, however, and can be influenced by a complex web of environmental conditions and ecological interactions. Among hypotheses that disease, changes in river water discharge (Havens et al. 2013), or reduced shell availability for spat settlement (Pine et al. 2015) may have led to recent Florida population declines, increased predation is another suspected cause (Kimbro et al. 2017)

1. This document is FA228, one of a series of the School of Forest Resources and Conservation, Program in Fisheries and Aquatic Sciences, UF/IFAS Extension. Original publication date September 2020. Visit the EDIS website at https://edis.ifas.ufl.edu for the currently supported version of this publication.

2. Gabrielle Love, graduate student; Shirley Baker, associate professor; and Edward V. Camp, assistant professor; School of Forest Resources and Conservation, Program in Fisheries and Aquatic Sciences, UF/IFAS Extension, Gainesville, Florida 32611.

The Institute of Food and Agricultural Sciences (IFAS) is an Equal Opportunity Institution authorized to provide research, educational information and other services

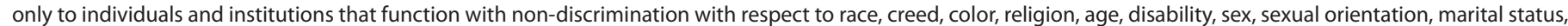

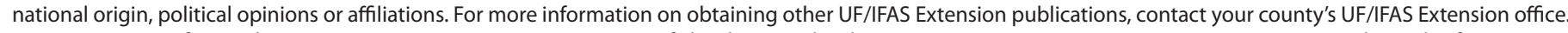
U.S. Department of Agriculture, UF/IFAS Extension Service, University of Florida, IFAS, Florida A \& M University Cooperative Extension Program, and Boards of County Commissioners Cooperating. Nick T. Place, dean for UF/IFAS Extension. 
Major predators of oysters include fish and invertebrates, such as crabs and snails. Increasingly, scientists believe that environmental or physical aspects like salinity, water temperature, and the structure of the oyster reef itself can influence how effectively predators hunt and kill oysters. These environmental aspects can also affect oyster natural mortality directly. As the climate changes, it is important to understand how these environmental and physical changes may translate into changes in oyster mortality dynamics. This fact sheet will describe key information about oyster mortality dynamics, how these dynamics may be affected by climate change, and what the effects of climate change on oyster mortality dynamics may mean for oyster management.

\section{Oyster Mortality Dynamics}

Oyster natural mortality is influenced by a number of physical or environmental factors like water temperature, $\mathrm{pH}$, and salinity. Mortality is also influenced by ecological interactions like density of prey or predators and competition for resources. Oyster mortality can vary substantially and sometimes rapidly under different ecological or environmental conditions that can change quickly. This means that even short-term changes in salinity or predator density (like those that might occur during droughts or floods) can affect mortality. Some of these shorter-term environmental changes will themselves likely become more frequent and/ or intense with climate change in Florida. The conditions that are predicted to result from climate change will have measurable impacts on oyster mortality in ways that can be simulated experimentally and studied to form well-founded predictions.

\section{The Direct Effects of Climate Change on Oyster Reefs}

There are several key ways in which climate change will alter estuaries and affect oyster reefs. Acidification is the decrease in overall oceanic $\mathrm{pH}$ as increasing amounts of atmospheric $\mathrm{CO} 2$ are absorbed by ocean waters (Sabine et al. 2004). Acidification threatens the shell strength of oysters and the structure of reefs. As the water becomes more acidic, juvenile oysters may struggle to grow their shells or have reduced growth, which will impact the health of individual oysters and their ability to construct reefs and which will cause existing shell reefs to disintegrate more quickly (Miller et al. 2009). Acidification is influenced by local geology, and, though it is occurring at a slower rate than in open ocean waters, estuarine oyster habitats are acidifying at similar rates across Florida (Robbins and Lisle 2018).

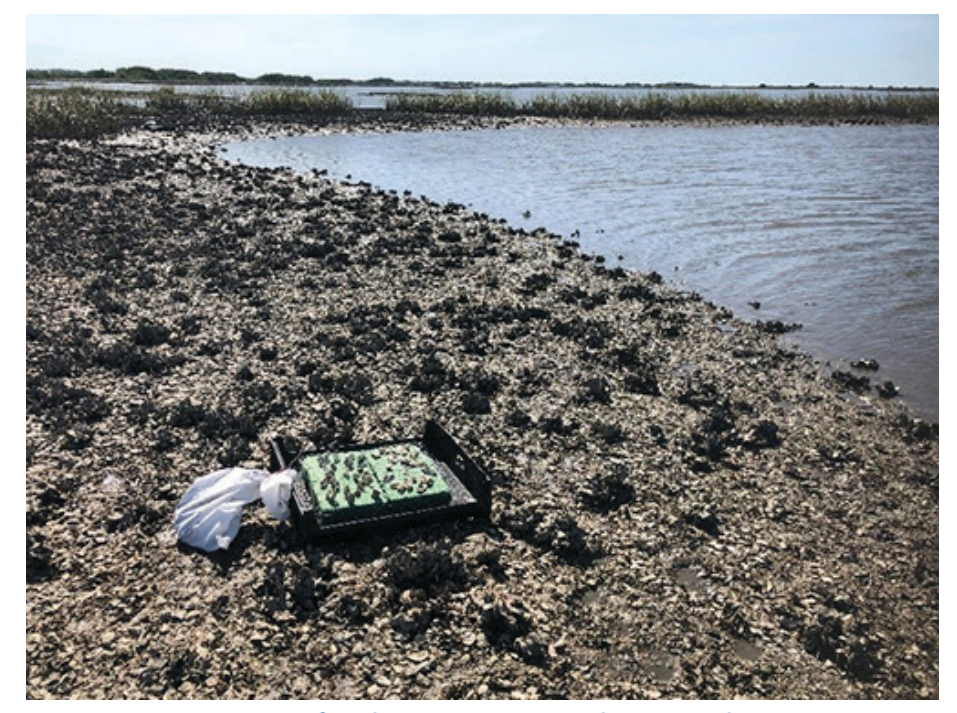

Figure 2. An oyster reef with an experimental tray used to assess changes in natural mortality.

Credits: G. Love, UF/IFAS.

Sea-level rise resulting from climate change may submerge intertidal reefs. The submerging of oyster reefs may increase oyster mortality. It could also change certain ecosystem services oyster reefs provide. For instance, it could reduce the ability of oyster reefs to decrease wave energy and prevent erosion.

Warming may push water temperatures beyond the optimal range for oyster physiological needs (Bayne 2017), while harmful algal blooms that may be more frequent or severe under climate change will likely increase oyster mortality (Pierce and Henry 2008) and may decrease oyster filtering efficiency (thus decreasing the "clean water" benefits they provide) (Matsuyama et al. 1999). Changes to filtering efficiency, however, are dependent on the type of algal bloom, and oysters may still be able to maintain feeding requirements even as they filter less water (Galimany et al. 2017). Changes in precipitation (total amount and variance) will alter the salinity in estuaries both directly (from rainfall) and indirectly by changing the volume of river water flowing into the estuary (Doney et al. 2012). The differences in conditions brought on by climate change will lead to altered interactions between oysters and their predators.

\section{The Effects of Climate Change on Oyster Predation}

As environmental conditions change, oysters and predator species alike will experience stresses that can impact their physiology and behavior. The current levels of predation experienced by specific reefs or oyster populations may change as oysters become more or less vulnerable to predation and as conditions become more or less favorable for predator foraging (Figure 3). 


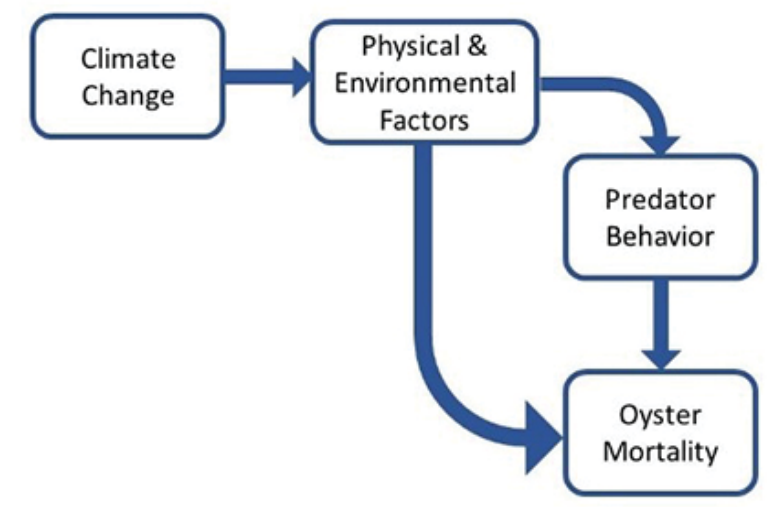

Figure 3. As climate change alters environmental conditions, oyster mortality will be affected via two pathways: directly through physiological responses and indirectly through changes to predator behavior.

Currently, subtidal oysters (those submerged most or all of the time) face a higher risk of predation by other reef-dwelling invertebrates than intertidal oysters (those submerged intermittently by tidal cycles) (Johnson and Smee 2014). If sea-level rise does indeed submerge some intertidal oysters, these newly subtidal oysters will face increased predation. Rodriguez et al. (2014) showed, however, that oysters may be able to construct higher reefs in response to rising sea levels. So, changes in predation vulnerability due to sea-level rise are uncertain.

Many species will respond to climate change by moving into different areas as current habitat becomes unsuitable and new locations become preferable. The movement of predator species means that prey living in regions that previously provided refuge from predators will become newly vulnerable (Doney et al. 2012). This is particularly true for oysters, an immobile species that are preyed upon by mobile invertebrates like crabs and snails. Because species that prey on oysters generally prefer higher salinities than oysters do, increased estuary salinity driven by decreases in river discharge may leave oysters without low-salinity refuge spaces (Kimbro et al. 2017). This is a suspected driver behind the Apalachicola Bay oyster population collapse; drought conditions lowered the flow of fresh water from the river into the estuary, increasing the salinity in the bay and allowing an outbreak of oyster predators (Kimbro et al. 2017).

The physiological responses by oysters to a changing environment may also leave them more vulnerable to predation. Oysters can grow in highly variable ways depending on the conditions in the exact location where they live. This includes altered growth for individual defense in response to higher predator presence (Lord and Whitlatch
2012). Oysters that have lived and grown in one part of a bay might not be as well defended as oysters that grew in another because of initial differences in predation risk. This means that "weaker" oysters would be more likely to die if they were targeted by predators that newly have access to the habitat (Robinson et al. 2014). Additionally, the physiological stress responses by oysters to changing water quality (like increasing temperature and $\mathrm{pH}$ or changing salinity) may hinder oysters' ability to defend themselves, further increasing their relative risk of predation (Menzel and Nichy 1958).

\section{Management for the Future of Oyster Reefs}

It is not easy to make confident predictions about how future changes in climate and predators will affect oysters. However, there are strategies to mitigate likely impacts of climate change on oyster reef ecosystems. Beyond actions to reduce climate change broadly, it is possible to develop management strategies for protection of oyster reefs specifically. The development of ecosystem-based management plans should take into account interactions within the system and take actions to preserve ecosystems, using ecosystem dynamics to reduce climate change impacts (Temmerman et al. 2013). Reef restoration is one example of this type of management strategy.

Successful restoration of oyster reefs would not only increase the oyster population but would improve the whole system by providing ecosystem services that would aid in climate change adaptation, such as shoreline buffering, substrate stabilization, and, in some cases, freshwater retention. A well-placed restoration project could act as a barrier, holding within the estuary some of the freshwater flowing from nearby rivers, thus preventing or reducing salinity increases (Frederick et al. 2015). This could, in turn, prevent predators from spreading into new habitat and reduce the predation on the reefs. Restoration efforts require extensive planning and funds, however, and will not work in all locations. River flow management projects could have similar effects, potentially maximizing oyster productivity and reducing predation by controlling river discharge and, thereby, estuary salinity (La Peyre, Gossman, and La Peyre 2009).

Oyster harvesters have an interest in dealing with oyster predators, and there are some options currently available. Some have already begun harvesting predatory conchs from the reefs and are attempting to create a market for the meat (Tilley 2013). Aquaculture also allows harvesters to have 
more control over the predation on their animals, depending on the culture style. Bag-and-longline culture provides protection from predators by excluding them with mesh bags around the oysters. Off-bottom culture styles elevate the oysters into the water column, where many invertebrate predators cannot access them. Additionally, young oysters can be reared in hatcheries until they grow large enough that they are less vulnerable to predation before being moved into natural habitats to grow to market size (FAO 2019).

\section{Conclusion}

Climate change will likely influence the natural mortality of oysters by influencing their physical environment and the interactions between oysters and their predators, though it is uncertain precisely how and how much mortality dynamics will change. Predator outbreaks may become more frequent, and potential strategies to mitigate the risk of increased oyster mortality will be complex and require more study. Aquaculture provides some methods for excluding predators from culture spaces, but no such methods currently exist for reducing the increased predation pressure that wild oyster reefs may face.

\section{Literature Cited}

Bayne, B. 2017. Biology of Oysters (Vol. 41). Academic Press.

Doney, S. C., M. Ruckelshaus, J. Emmett Duffy, J. P. Barry, F. Chan, C. A. English, H. M. Galindo, J. M. Grebmeier, A. B. Hollowed, N. Knowlton, J. Polovina, N. N. Rabalais, W. J. Sydeman, and L. D. Talley. 2012. "Climate Change Impacts on Marine Ecosystems." Annual Review of Marine Science 4(1): 11-37. https://doi.org/10.1146/ annurev-marine-041911-111611

FAO. 2019. Cultured Aquatic Species Information Programme: Crassostrea virginica. Food \& Agriculture Organization of the United Nations, Fisheries and Aquaculture Department. http://www.fao.org/fishery/culturedspecies/ Crassostrea_virginica/en

Frederick, P., B. Pine, J. Seavey, and L. Sturmer. 2015. Restoring Resilient Oyster Reefs in Florida's Big Bend (49 p.). Final Report to The Nature Conservancy and the National Oceanic and Atmospheric Administration. [Project Report].

Galimany, E., J. Lunt, C. Freeman, S. Reed, I. SeguraGarcía, and V. Paul. 2017. "Feeding Behavior of Eastern Oysters Crassostrea virginica and Hard Clams Mercenaria mercenaria in Shallow Estuaries." Marine Ecology Progress Series 567: 125-137. https://doi.org/10.3354/meps12050

Grabowski, J. H., and C. H. Peterson. 2007. "Restoring Oyster Reefs to Recover Ecosystem Services." In Ecosystem Engineers: Concepts, Theory, and Applications, edited by K. Cuddington, J. E. Byers, W. G. Wilson, and A. Hastings. 281-298. Amsterdam: Elsevier-Academic Press.

Havens, K., M. Allen, E. Camp, T. Irani, A. Lindsey, J. G. Morris, A. Kane, D. Kimbro, S. Otwell, B. Pine, and C. Walters. 2013. Apalachicola Bay Oyster Situation Report (Technical Publication No. 201; p. 32). University of Florida Sea Grant.

Johnson, K. D., and D. L. Smee. 2014. "Predators Influence the Tidal Distribution of Oysters (Crassostrea virginica)." Marine Biology 161: 1557-1564. https://doi.org/10.1007/ s00227-014-2440-8

Kimbro, D. L., J. W. White, H. Tillotson, N. Cox, M. Christopher, O. Stokes-Cawley, S. Yuan, T. J. Pusack, and C. D. Stallings. 2017. "Local and Regional Stressors Interact to Drive a Salinization-Induced Outbreak of Predators on Oyster Reefs." Ecosphere 8(11): e01992. https://doi. org/10.1002/ecs2.1992

La Peyre, M. K., B. Gossman, and J. F. La Peyre. 2009. "Defining Optimal Freshwater Flow for Oyster Production: Effects of Freshet Rate and Magnitude of Change and Duration on Eastern Oysters and Perkinsus marinus Infection." Estuaries and Coasts 32(3): 522-534. https://doi. org/10.1007/s12237-009-9149-9

Lord, J. P., and R. B. Whitlatch. 2012. "Inducible Defenses in the Eastern Oyster Crassostrea virginica Gmelin in Response to the Presence of the Predatory Oyster Drill Urosalpinx cinerea Say in Long Island Sound." Marine Biology 2012(159): 1177-1182. https://doi.org/10.1007/ s00227-012-1896-7

Lorenzen, K., C. Ainsworth, S. Baker, L. Barbieri, E. Camp, J. Dotson, and S. Lester. 2017. "Climate Change Impacts on Florida's Fisheries and Aquaculture Sectors and Options for Adaptation." In Florida Climate Institute, Florida's Climate: Changes, Variations, \& Impacts. Florida Climate Institute. https://doi.org/10.17125/fci2017.ch14

Matsuyama, Y., T. Uchida, and T. Honjo. 1999. “Effects of Harmful Dinoflagellates, Gymnodinium mikimotoi and Heterocapsa circularisquama, Red-tide on Filtering Rate of Bivalve Molluscs.” Fisheries Science 65(2). 
Menzel, R. W., and F. E. Nichy. 1958. "Studies of the Distribution and Feeding Habits of Some Oyster Predators in Alligator Harbor, Florida." Bulletin of Marine Science of the Gulf and Caribbean 8(2): 125-145.

Miller, A. W., A. C. Reynolds, C. Sobrino, and G. F. Riedel. 2009. "Shellfish Face Uncertain Future in High CO2 World: Influence of Acidification on Oyster Larvae Calcification and Growth in Estuaries." PLoS ONE 4(5): e5661. https:// doi.org/10.1371/journal.pone.0005661

NOAA. 2019. Annual Commercial Landing Statistics [Data file]. Retrieved from https://www.st.nmfs.noaa.gov/pls/ webpls/MF_ANNUAL_LANDINGS.RESULTS

Pierce, R. H., and M. S. Henry. 2008. "Harmful Algal Toxins of the Florida Red Tide (Karenia brevis): Natural Chemical Stressors in South Florida Coastal Ecosystems." Ecotoxicology 17(7): 623-631. https://doi.org/10.1007/ s10646-008-0241-x

Pine, W., C. Walters, E. Camp, R. Bouchillon, R. Ahrens, L. Sturmer, and M. Berrigan. 2015. "The Curious Case of Eastern Oyster Crassostrea virginica Stock Status in Apalachicola Bay, Florida." Ecology and Society 20(3). https://doi. org/10.5751/ES-07827-200346

Robbins, L. L., and J. T. Lisle. 2018. "Regional Acidification Trends in Florida Shellfish Estuaries: A 20+ Year Look at $\mathrm{pH}$, Oxygen, Temperature, and Salinity." Estuaries and Coasts 41(5): 1268-1281. https://doi.org/10.1007/ s12237-017-0353-8

Robinson, E., J. Lunt, C. Marshall, and D. Smee. 2014. "Eastern Oysters Crassostrea virginica Deter Crab Predators by Altering Their Morphology in Response to Crab Cues." Aquatic Biology 20: 111-118. https://doi.org/10.3354/ ab00549

Rodriguez, A. B., F. J. Fodrie, J. T. Ridge, N. L. Lindquist, E. J. Theuerkauf, S. E. Coleman, J. H. Grabowski, M. C. Brodeur, R. K. Gittman, D. A. Keller, and M. D. Kenworthy. 2014. "Oyster Reefs Can Outpace Sea-Level Rise." Nature Climate Change 4(6): 493-497. https://doi.org/10.1038/ nclimate2216

Sabine, C. L., R. A. Feely, N. Gruber, R. M. Key, L. Kitack, J. L. Bullister, R. Wanninkhof, C. S. Wong, D. W. R. Wallace, B. Tilbrook, F. J. Millero, T. -H. Peng, A. Kozyr, T. Ono, and A. F. Rios. 2004. "The Oceanic Sink for Anthropogenic CO2." Science 305(5682): 367-371. https://doi.org/10.1126/ science. 1097403
Temmerman, S., P. Meire, T. J. Bouma, P. M. J. Herman, T. Ysebaert, and H. J. De Vriend. 2013. "Ecosystem-Based Coastal Defence in the Face of Global Change." Nature 504(7478): 79-83. https://doi.org/10.1038/nature12859

Tilley, J. 2019. "Is there hope for restoring the bay?" The Apalachicola Times. Retrieved from https://www.apalachtimes.com/news/20190307/is-there-hope-for-restoring-bay 